Energy Research Journal 1 (1): 1-5, 2010

ISSN 1949-0151

(C) 2010 Science Publications

\title{
Dissolved Ammonia Adsorption in Water Using Over Burnt Brick
}

\author{
Shukra Raj Paudel and Bhagwan Ratna Kansakar \\ Department of Civil Engineering, Tribhuvan University, Institute of Engineering, \\ Pulchowk Campus, Pulchowk, Lalitpur, Nepal
}

\begin{abstract}
Problem statement: The groundwater of Kathmandu Valley contained very high concentration of ammonia nitrogen which was in excess of WHO guideline value for drinking water. Approach: This study mainly focused on the removal of ammonia nitrogen in water by adsorption in locally available over burnt brick. The study was carried out in a $4.2 \mathrm{~cm}$ internal diameter column of $120 \mathrm{~cm}$ length packed with over burnt brick in up flow mode. Results: The study showed that the ammonia nitrogen removal rate increased with increase in contact time which decreased with time until steady state condition is attained. The contact time varied from 4-9.5 h for different particle sizes. Conclusion: The optimal value of adsorption rate constant was found as 0.1097 for particle size of $0.850-0.600 \mathrm{~mm}$ at corresponding contact time of $7 \mathrm{~h}$. The adsorption data appears to fit the Freundlich's isotherm. The fixed bed adsorption operation indicated that the ammonia nitrogen removal is the function of service time, bed depth and flow. Linear regression model showing correlation of these parameters has been developed.
\end{abstract}

Key Words: Kinetics, contact time, isotherms, column study and linear regression

\section{INTRODUCTION}

Ammonia is a natural by-product of the decomposition of various types of organic matter. The occurrence of free ammonia indicates the direct inclusion of organic matter, particularity those arising from the excrement of animal and human species. Surface water may also get polluted ammonia due to industrial discharges. Groundwater drawn from strata overlay with clay may sometimes suffer deoxygenating and comparatively large quantities of free ammonia can arise from the reduction of nitrate. In populated area, incompletely treated sewage or possibly industrial effluent may be another source. The ammonia also sometimes found in groundwater as a result of breakdown of portentous organic matter and reduction under anaerobic conditions. Various sources of nitrogen in water supplies have been reported in Carty et al. (1967).

Groundwater quality of Kathmandu valley is degraded up to different level due to contamination. Most of local areas have been experienced with excessively high level of nitrogenous compounds. The groundwater resource development board (GWRDB, 1989) has reported the concentration of ammonia in surface and groundwater as presented in Table 1. The ammonia concentration up to 19 and $95 \mathrm{ppm}$ have been reported in surface water and groundwater respectively. The ammonia concentration on the surface and groundwater as reported by Amatya (2004) is presented in Table 2. In drinking water, the ammonia should not exceed $1.5 \mathrm{ppm}$ (WHO, 1990). The ammonia concentration was found to exceed the WHO guideline values in both the surface and ground waters. The ammonia nitrogen concentration up to $125.07 \mathrm{ppm}$ has been reported. The ammonia nitrogen concentration increases as the depth of wells increases.

Some methods such as adsorption, reverse osmosis, chemical precipitation, chemical oxidation, electrolysis, gas stripping and biological nitrification or denitrification can be used for removal of ammonia from water (USEPA, 1975; Culp and Culp, 1971; Kansakar, 1986; Carty et al., 1967; Miller and Short, 1972; Short, 1975). Although the many of them proved to be technically feasible but others factors such as cost, operational requirements and aesthetic considerations have not been found favorable in some cases.

Table 1: Ammonia nitrogen concentration in Kathmandu valley

\begin{tabular}{|c|c|c|c|c|c|}
\hline \multirow[b]{2}{*}{ Parameter } & \multirow{2}{*}{$\begin{array}{l}\text { WHO } \\
\text { guideline }\end{array}$} & \multicolumn{2}{|c|}{ Surface water } & \multicolumn{2}{|c|}{ Ground water } \\
\hline & & $\operatorname{Max}$ & Min & $\operatorname{Max}$ & Min \\
\hline Ammonia-N (ppm) & 1.5 & 19 & $<0.1$ & 95 & 0.1 \\
\hline
\end{tabular}

Corresponding Author: Shukra Raj Paudel, Department of Civil Engineering, Tribhuvan University, Institute of Engineering, Pulchowk Campus, Pulchowk, Lalitpur, Nepal 
For low concentration of ammonia in water, adsorption of ammonia by using over burnt brick in local level may be very practical and economical. The main objective of this study is to minimize the ammonia concentration in surface water and groundwater and the performance study of locally available adsorption media like over burnt brick.

\section{MATERIALS AND METHODS}

The ammonia nitrogen adsorption on over burnt brick was carried out in column using fixed bed operation. The study was conducted in a small column having internal diameter of $4.2 \mathrm{~cm}$ and length of $120 \mathrm{~cm}$ with upflow mode. A perforated plate with cotton was placed at the base of the column that acted as support for the media. Arrangements were made to measure the loss of head during the operation. Four ports $\left(\mathrm{P}_{1}, \mathrm{P}_{2}, \mathrm{P}_{3}\right.$ and $\mathrm{P}_{4}$ ) were provided on the column to take the sample from different depths. The column is filled up with over burnt brick of sizes $0.60-0.85 \mathrm{~mm}$ up to $80 \mathrm{~cm}$ height. The influent ammonia nitrogen concentration was fixed at 2.5 and $5 \mathrm{ppm}$. The experiments were conducted at flow rates of $123.84 \mathrm{~m}^{3} \mathrm{~m}^{-2}$ day $^{-1}\left(120 \mathrm{~mL} \mathrm{~min}{ }^{-1}\right)$, $36.80 \mathrm{~m}^{3} \mathrm{~m}^{-2}$ day $^{-1}\left(130 \mathrm{~mL} \mathrm{~min}{ }^{-1}\right)$ and $150.77 \mathrm{~m}^{3} \mathrm{~m}^{-2}$ day $^{-1}\left(145 \mathrm{~mL} \mathrm{~min}^{-1}\right)$. The schematic diagram of experimental setup is shown in Fig. 1.

Table 2: Ammonia nitrogen concentration of deep wells in Kathmandu valley

\begin{tabular}{ll}
\hline Location & Ammonia-N (ppm) \\
\hline Lokanthali WTP & $51-105$ \\
Kuleshor & $60-95$ \\
IOE Pulchowk campus & $40-117$ \\
Balaju & $21-38$ \\
Bhaisepati & $10-43$ \\
\hline
\end{tabular}

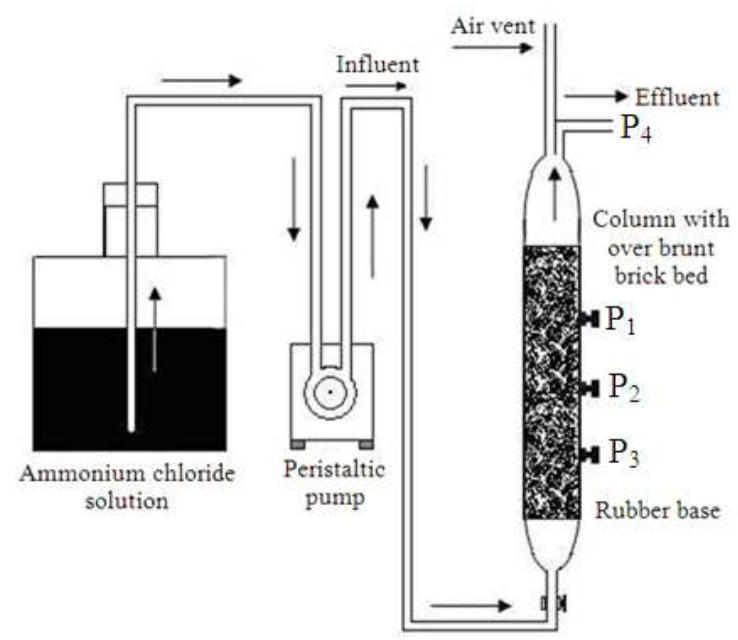

Fig. 1: Schematic diagram of experimental set up
The flow was regulated by using Watson inducer (MHRE MK 4 flow inducer) and Electrolab Peristaltic Pump (PP $50 \mathrm{VX}$ ). The $\mathrm{pH}$ was measured by digital $\mathrm{pH}$ meter (DHA-3000-1706-02) and the temperature was measured by simple thermometer graduated in $\left({ }^{\circ} \mathrm{C}\right)$. The ammonium nitrogen concentration was measured by using Ultra violet spectrophotometer as per the Standard Methods, (APHA-AWWA-WPCF, 1981).

\section{RESULTS}

The adsorption equilibria are the most important physiochemical parameters, which help in defining the type and process of adsorption. The ammonia nitrogen adsorption equilibria study using different particles sized over burnt brick adsorbents were conducted utilizing non flow agitated system. The adsorption of ammonia nitrogen was observed at equilibria in all particles sizes. Therefore contact time was perceived at time taken for $90 \%$ adsorption from the aqueous solution of adsorbate. It was noticed that for all particles size the rate of adsorption processed quite rapidly and attained equilibrium gradually as presented in Fig. 2. This appears due to external surface reaction.

Figure 2 shows the removed $\mathrm{NH}_{3}-\mathrm{N}$ concentration and effluent $\mathrm{NH}_{3}-\mathrm{N}$ concentration as time progressed. The initial concentration start decreasing as time increase, thus by increasing removed $\mathrm{NH}_{3}-\mathrm{N}$ concentration.

\begin{tabular}{lll}
\multicolumn{3}{l}{ Table 3: Contact time and adsorption rate constant } \\
\hline Particle size $(\mathrm{mm})$ & Contact time $(\mathrm{h})$ & Adsorption rate constant \\
\hline $0.30-0.150$ & 4.0 & 0.0540 \\
$0.425-0.30$ & 5.5 & 0.0615 \\
$0.60-0.425$ & 6.0 & 0.0653 \\
$0.85-0.600$ & 7.0 & 0.1079 \\
$1.18-0.850$ & 8.0 & 0.0977 \\
$2.00-1.180$ & 8.5 & 0.0898 \\
$2.36-2.000$ & 9.0 & 0.0846 \\
$>2.36$ & 9.5 & 0.0763 \\
\hline
\end{tabular}

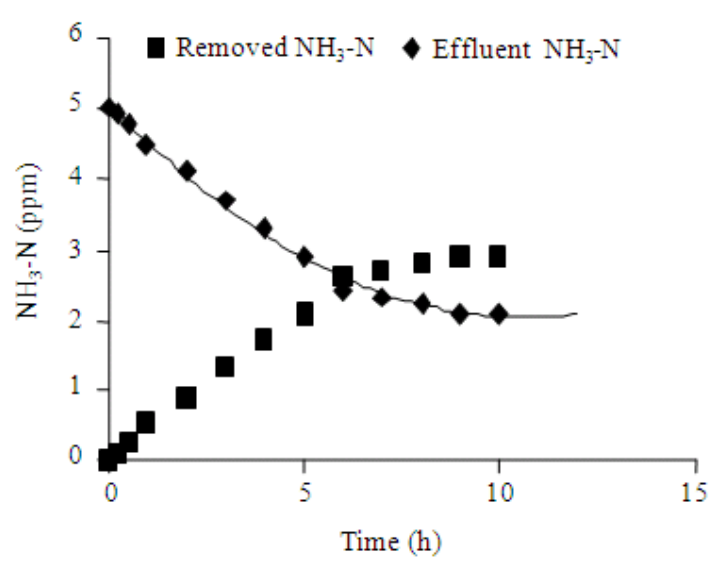

Fig. 2: Ammonia-N removal 
Energy Rec. J. 1 (1): 1-5, 2010

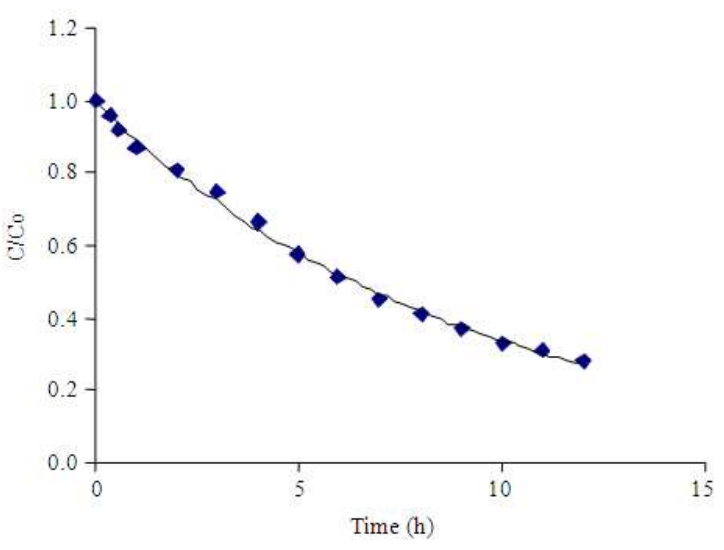

Fig. 3: Contact time Vs C/Co

Figure 3 shows the ratio of $\mathrm{C} / \mathrm{Co}$ at various contact time, where $\mathrm{C}$ is ammonia nitrogen concentration and Co is the initial ammonia nitrogen concentration. The contact time and adsorption rate constant for various particle sizes at initial ammonia concentration of $5 \mathrm{mg} \mathrm{L}^{-1}$ is presented in Table 3. The contact time of smaller particle size was less as compared to larger particles sizes. The contact time increased as the particle sizes increased. The contact time is calculated as $4 \mathrm{~h}$ for particle size of $0.30-0.15 \mathrm{~mm}$ which increased to $9.5 \mathrm{~h}$ for particle size greater than $2.36 \mathrm{~mm}$. The effluent ammonia nitrogen concentration decreases as the contact time increases.

The variation of contact time with respect to particle size is presented in Fig. 5. The contact times for various types and sizes of adsorbents were calculated to illustrate the time dependence of the system. Although the removal of ammonia nitrogen was high initially, the rate gradually decreased to attain the equilibrium stage.

Table 3 shows that as the particle size increases the adsorption rate constant also increase up to particle size of $0.060 \mathrm{~mm}$. However the adsorption rate constant decreases for the particle sizes from $0.850-2.36 \mathrm{~mm}$. The optimal value of adsorption rate constant was found as 0.1097 for particle size of $0.850-0.600 \mathrm{~mm}$ at corresponding contact time is $7 \mathrm{~h}$.

\section{DISCUSSION}

Adsorption isotherms: The adsorption curves for various sizes-adsorbents were applied to Langmuir's and Freundlich's equations. The Freundlich's curves fit better than Langmuir curve and also linear. It can be observed that all the isotherms of media seem favorable for the adsorption data. Typical examples of isotherm test for media size of $2.36-2.0 \mathrm{~mm}$ are presented in Fig. 4 and 5, Similar patterns were noticed for others particle sizes. In graphs, $X$ and $\mathrm{m}$ are the weight of substance adsorbed (contaminant) by adsorbent and weight of adsorbent (media) respectively.

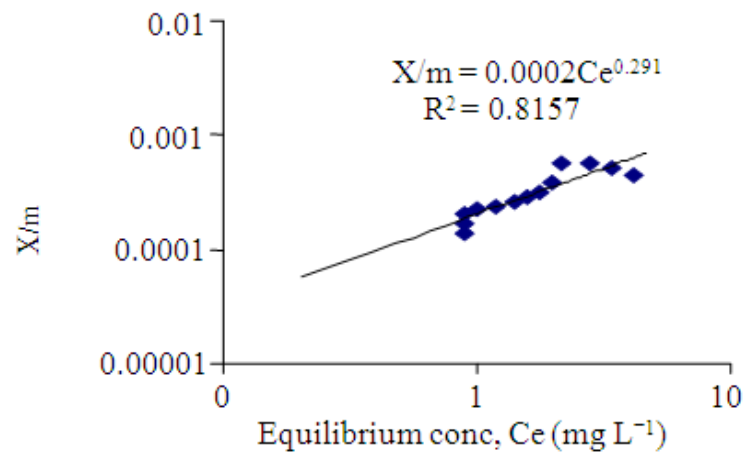

Fig. 4: Freundlich's isotherm test

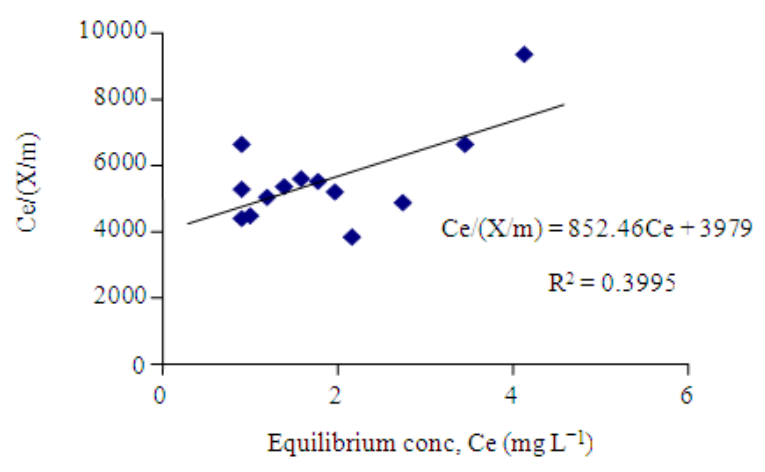

Fig. 5: Langmuir isotherm test

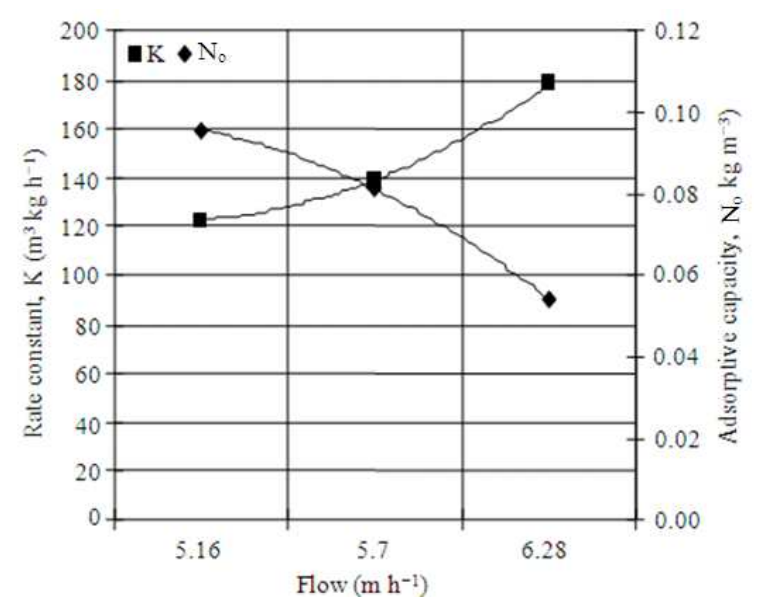

Fig. 6: Adsorption capacity and rate constant

Column study: The column study was carried out for ammonia nitrogen adsorption capacity in the fixed bed column containing over burnt brick. The ammonia nitrogen concentration at various flows and bed depths i.e., $\mathrm{P}_{1}$ (port at $20 \mathrm{~cm}$ depth), $\mathrm{P}_{2}$ (port at $40 \mathrm{~cm}$ depth), $\mathrm{P}_{3}$ (port at $60 \mathrm{~cm}$ depth), and $\mathrm{P}_{4}$ (port at $80 \mathrm{~cm}$ depth) were measured and their breakthrough curves are presented in Fig. 6. 


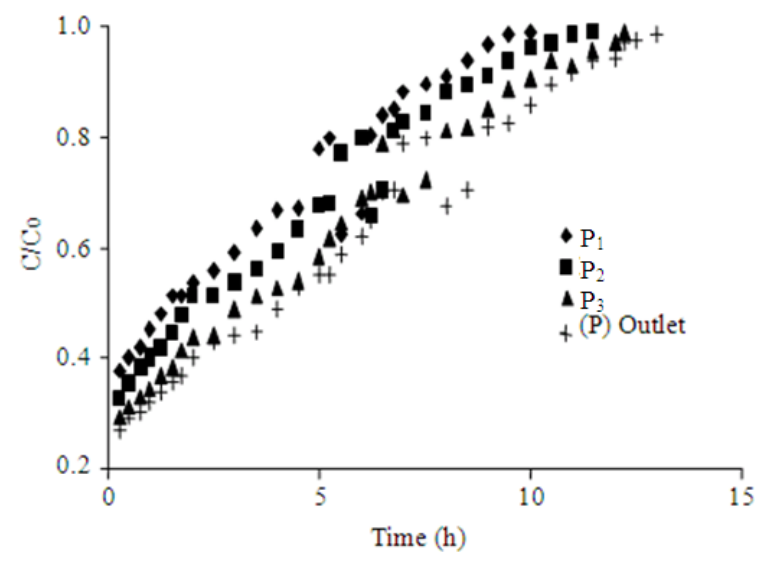

Fig. 7: Breakthrough curve for $\mathrm{NH}_{3}-\mathrm{N}$ adsorption

It was noticed that as flow decreased and or bed depth increased, the trend of effluent concentration is flatter and vice versa. At the time of attaining exhaustion the slope was more flat in low flow and less flat in high flow rate. Figure 6 shows that the exhaust time at the various depths of media at flow of $120 \mathrm{~mL} \mathrm{~min}^{-1}$.

The rate constant $(\mathrm{K})$ and adsorptive capacity $\left(\mathrm{N}_{\mathrm{o}}\right)$ for over burnt brick of $0.850-0.600 \mathrm{~mm}$ size are presented Fig. 7. It can be seen at various flow rates that as flow increases, the rate constant increases while adsorptive capacity decreases.

Linear regression analysis: In order to develop relationship between ammonia removals, depth of media, flow rate and service time, linear regression analysis was done using SPSS as a tool. The mathematical model developed is given below:

$\Delta \mathrm{N}=\mathrm{CH}^{0.084} \mathrm{Q}^{0.514} \mathrm{~T}^{0.521}$

Where:

$\Delta \mathrm{N}=$ Ammonia- $\mathrm{N}$ removed $(\mathrm{ppm})$

$\mathrm{H}=$ Depth of media $(\mathrm{cm})$

$\mathrm{Q}=$ Discharge to be supplied $\left(\mathrm{L} \mathrm{min}^{-1}\right)$

$\mathrm{T}=$ Service time $(\mathrm{min})$

$\mathrm{C}=$ Constant coefficient $(\mathrm{C}=$ Antilog $(-1.267))$

The above regression model can be used for design purpose i.e., size of treatment plant to adsorb ammonia nitrogen by using over burnt brick. This model considers only the major parameters such as depth of media required, ammonia nitrogen concentration to be removed, service time and discharge while other parameters like temperature, $\mathrm{pH}$ remaining constant.

\section{CONCLUSION}

Following conclusions have been drawn from the study:

- The ammonia nitrogen removal rate increased with increase in contact time at the initial phase, which decreases with time until steady state condition is attained

- The contact time and the rate of adsorption (K) increase with increase in particle size. The optimum value of adsorption rate constant was found at particle size of $0.850-0.600 \mathrm{~mm}$, and then rate of adsorption decreased as the particle size increased

- Freundlich's isotherms were found best to describe the ammonia nitrogen adsorption of over burnt brick

- As the discharge increases, adsorption capacity of over burnt brick decrease where as rate constant and critical bed depth increase

- The linear regression mathematical model developed will be helpful for calculating ammonia removal in fixed bed applications

\section{ACKNOWLEDGEMENT}

I wish to express my deep sense of gratitude and sincere thanks to Prof. Dr. Bhagwan Ratna Kansakar and Associate Professor Mr. Iswar Man Amatya for their excellence guidance, constant inspiration, regular monitoring and all round assistance that enabled me to bring this research work in present form.

I extend my profound gratitude to Prof. Dr. Vinod Tare of Environmental Engineering, IITK for his valuable suggestions.

I express my sincere thanks and gratitude to $\mathrm{Mr}$. Mahesh Prasad Bhattarai, Coordinator of Environmental Engineering Program of Institute of Engineering, for his valuable suggestion during literature collection.

My thanks also go to Asso. Prof Padma Sundar Joshi of IOE for his all round supports. I would also like to extend my appreciation to Mr. Nagendra Bahadur Amatya for his valuable suggestion during data analysis.

Finally, I would like to thanks to Mrs. Prabha Karmacharya, Miss Goma Yakami, Mr. Keshab Bhattari and Mr. Sagar Devkota for their kind cooperation extended during the research work.

\section{REFERENCES}

Amatya, I.M., 2004. Ammonia removal in water. Directed study submitted in partial fulfillment of the requirement for Ph.D. Study, Institute of Engineering. 
APHA-AWWA-WPCF, 1981. Standard Method for the Examination of Water and Wastewater. 15th Edn., American Public Health Association, ISBN: 087553094X.

Carty, M.P.L., et al., 1967. Source of nitrogen and phosphorous in water supplies. J. Am. Water Works Assoc., 59: 345-366.

Culp, R.L. and G.L. Culp, 1971. Advanced Wastewater Treatment. Van Nostrand Remold, University of Michigan, New York, pp: 310.

GWRDB., 1989. A report on ground water management project in the Kathmandu valley. Report No. 574, Japan International Cooperation Agency, (JICA).
Kansakar, B.R., 1986. Nitrification of water in gravel filters for drinking purpose. Thesis, Tokyo University, Tokyo, Japan.

Miller, D.G. and C.S. Short, 1972. Costs of Water Treatment. The Trent Research Programme, Water Resources Board, 5.

Short, C.S., 1975. Removal of ammonia from river water. Water Research Centre, Medranham, Bucks, Technical Report TR-3.

USEPA., 1975. Process Design Manual for Nitrogen Control. Office of Technology, Washington DC.

WHO., 1990. Health and safety guidelines. 